\title{
Keris Symbols in The Emblem and Brand Logo
}

\author{
Handriyotopo ${ }^{1}$, and Lono Lastoro Simatupang ${ }^{2}$ \\ ${ }^{1}$ Lecturer at Visual Communication Design Study Program, Faculty Fine Art dan Design \\ Indonesian Institute of the Arts in Surakarta, City, Country \\ ${ }^{2}$ Lecturer at Postgraduate School, Gajah Mada University \\ Email: oxcy.solo@gmail.com
}

\begin{abstract}
The Keris as a result of Indonesian culture that existed in the archipelago was born since this ancestor experienced a cultural change from agrarian culture to metallurgical culture that synergize with human behavior. As a worthy artifact, keris has a personal philosophy value for the wearer, where the keris contains elements of prestige result of the wrought process is quite complicated. If modern civilization the keris disappears from the nation's cultural behavior is due to the process of cultural hegemony outside and erodes the value of the local culture. This study uses a qualitative descriptive approach to analyze the function of keris icon in the symbol or brand in hermeunitic and interpret it in semiotic. So that the current keris interpreted as a symbolic visual element, then the form of a keris that curves and kris straight into the aesthetic elements of the logo or symbol in it. From several symbols or logos showing positive values have a strong philosophy of spirit and unity in the symbols of provinces and districts in Indonesia. Similarly there is the national army corps like corps Marines, symbols in the world of sports such as martial arts and exist in the college logo. But there are other things as a symbol element that is worth the economic identity, as in the brand Batik Keris, and also on other brands in the realm of postmodernism contains elements of capital.
\end{abstract}

Keywords Keris, emblem, logo, brand, and corporate identity

\section{Introduction}

The advancement of human culture technology enables all human efforts to image themselves. No exception with the products that we use today. The objects that stick into our bodies as cover like clothes have a trademark identity that shows a lifestyle. The treatment of communication media like television struck us constantly before us. As gadget with the online media, the television also infiltrated in the android media space in streaming format.

Advertisements have been made in quite a lot of variants both electronic and printing. This ever-present every time of advertisements gives us advantages to choose the best. If we do not filter all of the persuasion of advertisement, our homes will be filled with these commercial material we likes. Ads containing local cultural icons such as keris are a branding that allows a reverse connotation with the creator's intent and the intentions of the recipient.

Many visual image of keris raised not only in television and printing advertisement, but also on logo and symbol of brand. On the local television icon also shows a visual image of keris used as the identity of local television stations. So the keris has hegemonied not just as a traditional sharp weapon in Javanese culture or indigenous Javanese clothing, but also used as another attribute that is as an iconicity in the symbol or brand.

Keris seemed timeless in the time-period as a product of Indonesian nation culture in the archipelago. The stories about the myth of keris also become the background on the script of the story of Javanese culture. In Ketoprak and puppet stories, keris appear as a weapon that is quite strong and powerful. The heroes also use the keris as an icon that contains the toughness and the spirit of struggle against the invaders like Prince Diponegoro who rode a horse, and Sultan Hasanudin who wore it tucked in front of his body.

The existence of keris as a symbol of men is a matter that needs to be observed at this time where the value of cultural modernity of dress affects on custom dressed especially Java. Keris is now only as a complementary part of Kejawen clothing. It is explained that in ancient time before the invaders entered Java, the keris reportedly used as a complementary everyday men's clothing because it shows the value of masculinity. There is no exception from the small children to adult wear them. When the men defend his honor, then the keris is assumed as a weapon of selfdefense and used for attacking the enemy if necessary.

\section{Shape of Keris}

The shape or the form of a keris is made of metal and steel which the process of manufacture requires high persistence and patience in melting in order to make a keris by the Keris-maker (Empu). The art of a keris is elegant and artistic because it contains a form the ornaments to make it 
look beautiful, what is so called with pamor. Pamor of keris as a form of visual ornamentic that gives the philosophy values for the owner. So it is not surprising if the keris becomes strong for the owner who bring it as a mystical meaning. These values of mysticism in the view of Java means that the power of keris was not formed suddenly, because it comes from the process of wrought in making keris done with the spiritual behavior first. The behavior of the keris-maker for example do fasting (mutih or ngebleng) and offerings in spiritual customs of Java.

The form of a keris is a keris-shaped straight and winding (ber-luk). It is said that a straight keris is often worn by the nobles rather than the winding ones. Keris aesthetically contains symbolic and philosophical meanings. There are two kinds of keris according to the history, there are ancient keris and Buddha keris. We assess the keris from aspects of dhapur, pamor, and style (tangguh) and aspect of the mystic soul (tuah). Dhapur is a form or shape of the keris, for example dhapur sengkelat, etc. Pamor is a motif or ornament that represents a painting that emerged from a keris when the process of forging and folding. Then style (tangguh) is related to the time of the making of keris. Such as tangguh Majapahit, Mataram, Singosari etc. The tuah is related to the spiritual value achieved when the Empu (keris-maker) makes it.

Keris is made of steel and nickel material as well as meteorite material. Its existence is now as a collection of esthetic and symbolic value. More explicitly said by Guntur, as Indonesia's cultural heritage, keris not only reflects the peak achievement of technical ability with artistic sophistication, but also reflects the peak achievement of philosophy. Besides, the function of a keris is not only as a tool of war, but also as a complementary of offerings. Keris according to its origin can be found in relics of cultural artefacts on the temple relief. Initially, it's found a temple containing the reliefs of blades and also keris at the Prambanan temple, Penataran temple, Borobudur and Sukuh temple ranged from the $9^{\text {th }}$ to $15^{\text {th }}$ century AD. The oldest visual data about the existence of stabbing weapons can be seen in the relics of the megalithic period in Pasemah called 'Batu Gajah' (elephant stone). There in the relief is a figure that on his waist tucked a kind of blades that is probably it's the first type of keris. In the $19^{\text {th }}$ century when the Javanese people in the Hindu cultural period, some inscriptions stated the word 'keris', in ancient Javanese. Visually in the source of the reliefs, the form of a keris is found in Lingga (a phallus) in Sukuh temple. On the site of Sukuh temple, Karanganyar in Central Java was seen how the process of making a keris is done visibly on a relief.

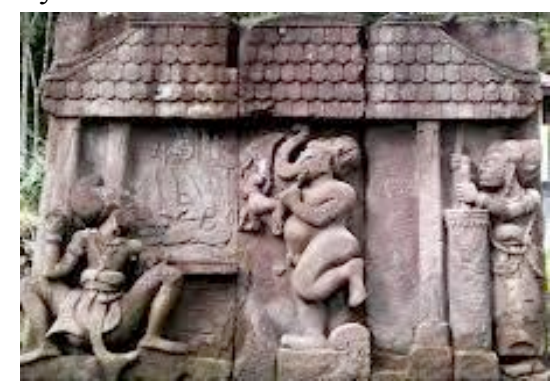

Fig. 01 Keris making process at relief of Sukuh temple, Karanganyar

\section{The Meaning of Symbolic Keris}

The value of the symbolic meaning of the keris is seen in the 'dhapur'. The meaning of the dhapur's names becomes philosophically valuable. Dhapur becomes a strong symbolic strength in addition to its 'pamor'. Ancient keris made with spiritual behavior to meet the spiritual value of the keris from the empu (keris-maker). From the perspective of kerisology then the symbolic meaning of dhapur keris has characteristic such as dhapur tilam upih, dhapur pudak jangkung, dhapur sempana, dhapur carang soka, dhapur sabuk inten, and dhapur sengkelat. Dhapur keris has different characteristic between one with the others. So giving the meaning on keris is not only one motif of dhapur keris, but also the form of keris straight and winding which amounts to hundreds. If interpreting the keris with symbolic value as a form of the value of Javanese mysticism then a keris is measured or interpreted based on the material content through messages containing moral and ethical values in the scope of macrocosm and microcosms. The relationship needs to be continuously to maintain the horizontal and vertical balance, which horizontal maintaining balanced itself (microcosm) and universe (macrocosm) in balance and maintaining a vertical balance for Oneness (God).

Keris is a part of the history of metallurgical development. Keris is as an ideo-technic artifact and can be included as a technomic artefact that was originally as a stabbing weapon. The symbolic aspects have colored society's view of metallurgy. Keris is as a heritage goods filled with symbolic meaning. This has arisen since the stage of creation as can be traced within the tradition of Krisology in traditional societies.

The meaning of philosophy of keris is in its motive or pamor. The mixing of the owner's expectations, the creations of the keris-maker and the strengths that exist in the quality of the metal, require thoroughness and tested choices. As the symbolic and philosophical characteristic that is sipat kandel, that the keris is expected to be able to provide the honour for the wearer. Keris has a full of symbolic meaning. The creation of a keris from a unique shape and stylist has a characteristic that is the pamor. Basically pamor is the result of unification or integration between iron with meteorite because the etymologically pamor comes from the word 'amor ' = fused, cohesive). Pamor is one of the most important aspects for the society in general, to determine how their attitude and appreciation to the existence of a keris physically. The term pamor is the application of painting a certain motif of the image on the surface of a keris blade, using materials derived from meteorite stones. Painting motifs of pamor images are actually a form of decorative images that appear on the surface of keris, ganja keris and even pesi keris, with manifestations arising from paintings, strokes (guratan), grooves (lekukan), protrusions (mberendhul), reliefs, or various other forms of appearance (samudana-samudana). No less interesting, it turns out that every painting of the pamor image motifs that appear on the surface of the eye/edge of a keris is generally also part of a particular symbol system. These symbols have the character, the values of meaning and hope (humane) and charisma that is often considered as magical. Many pamor 
image motifs choose, in the sense that they only correspond to the character of the person and the background of certain types of activities and occupations such as for motifs of pamor blarak sineret, ron ghanduru, singkir, etc.
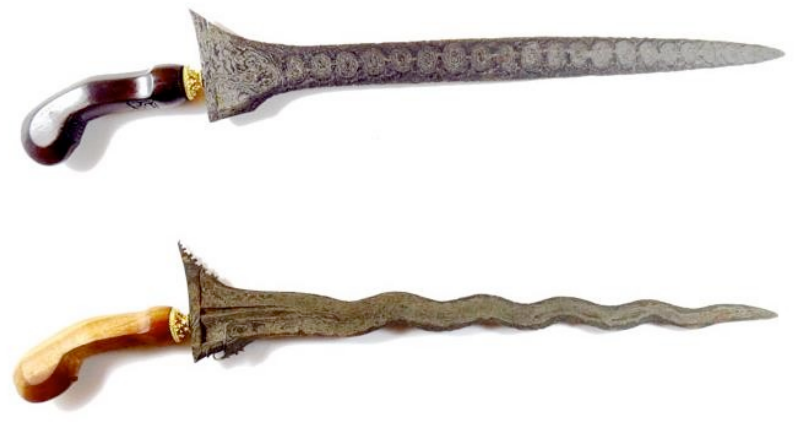

Fig.02 Straight keris and keris luk (winding)

\section{Iconicity Keris on Symbol, Logo and Brand}

Seeing the existence of a keris symbol on the brand of a commercial logo or other agencies at this time may have existed several years ago. Iconic or keris symbols of both straight keris and winding keris type, is used in the symbol of government and agencies in several provinces and districts in Indonesia. This means that the keris has a strong enough position of philosophical meaning for the community in Eastern spiritual belief especially in the archipelago. Symbol or logo in the world of visual communication and advertising is a form of marker or identity on the institution or other commercial business which is often called as the brand (mark).

In the current era of contemporary or postmodern values are also penetrated in the world of advertising by playing signs in it. It could be that the symbolizing or pastiche values appear in the symbol or logo by lifting the advertisement symbol and the keris as metaphor. The metaphor in KBBI (Indonesia Dictionary) online is the use of word or group of words not by real meaning, but rather as paintings based on the equations or comparisons which means the symbol of the language. The metaphorical visual rhetoric in symbols, logos, and brands is a sign language. In his writings, Yasraf said that pastiche's work, in this case it is very dependent on the existence of past culture and works and aesthetic idioms that existed before. Markers of symbols that lift the symbol of the keris is not made without meaning in it, because the elements of verbal and visual support each other. Katy Mayer says that the basic question sustains semiology analysis is how meaning is created. This question is also applied to analysis of text or images, because the solution lies in the identification of signifiers.

Marine Corps of the Navy put the keris image in the logo of the purple berets. This is in accordance with the function and main-work of the Marines to conduct an amphibious invasion of the sea. Several other TNI units also did the same. "The keris and the waves symbolize the Marines are the pricks from the sea," said the Marine Corps Commander, Maj. Gen. Djunaidi Djahri at Mabes AL Cilangkap, East Jakarta, Wednesday (4/11/2008).
Keris is also used as a symbol of patriotism and the heroic, so the picture is often used as one element of the symbol of the unity of the Indonesian National Army (TNI). Among these are the Marine Corps of the Navy and the Kodim VII Diponegoro. In addition, almost all districts and municipalities in the province of Central Java and some districts in East Java also includes pictures of keris in their symbol, both straight and the winding ones. In addition, businesses also use it as trademarks or logos.
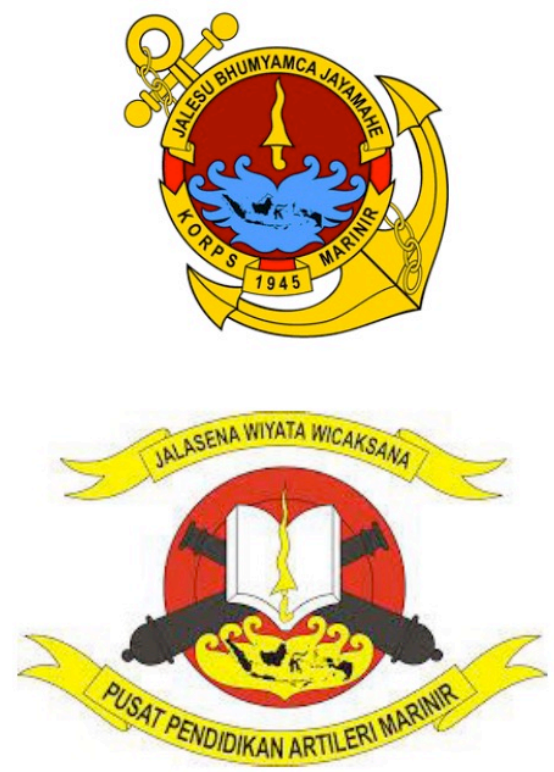

Fig. 03 Symbol of the TNI marine corps
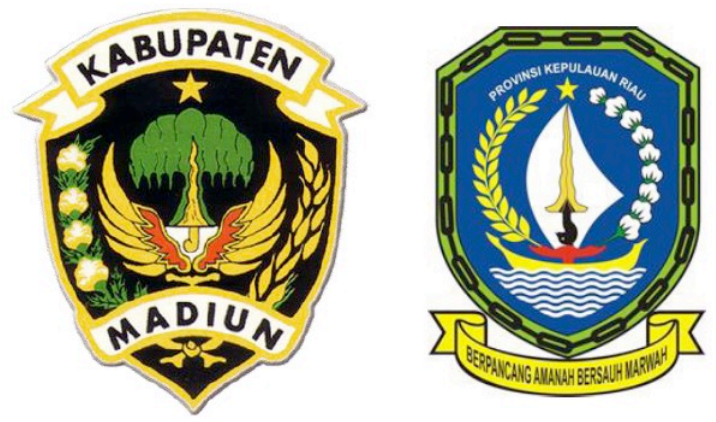

Fig. 04 Keris icon as a symbol in one of the regencies and provinces in Indonesia

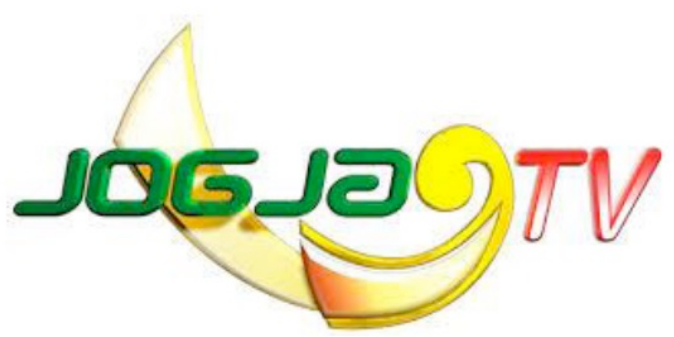

Fig. 05 Warangka keris as the logo of private TV Broadcasting Station 


\section{BatikKeris}

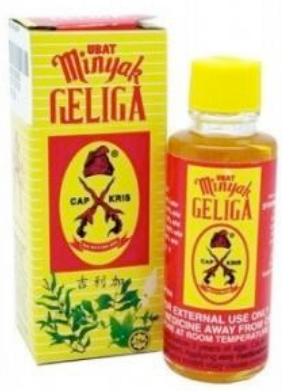

Fig. 06. Warangka and keris as an economic product brand
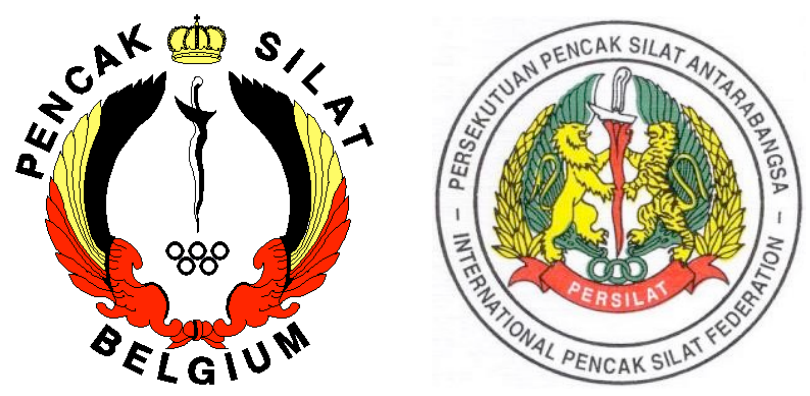

Fig. 07. Keris as an icon part of sports symbol, Pencak Silat
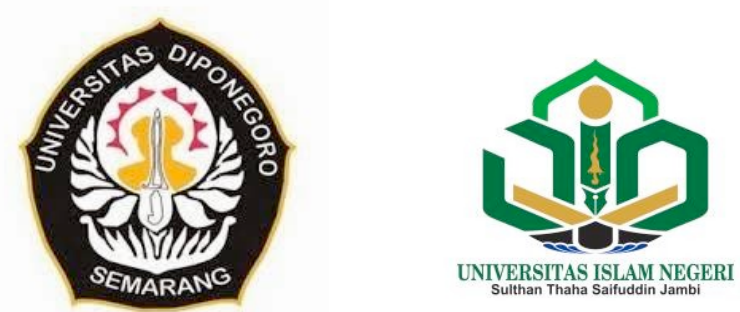

Fig.08. Keris icons in the symbol of higher education (university)

Looking at brands or symbols is very interesting to be studied in this case relating to the idioms of local identity that function symbolically appear in a trademark or symbol as product identity. A logo, symbol, brand contains a symbolic element in it. People will understand the text of the symbol that is created in such a fascinatingly meaningful way. Symbol or logo includes a symbol in it which there is an aesthetic value. Susana K. Langer who revealed the theory of symbols. She mentions it as an "art symbol." She sees an aesthetic of art through expressions, emotions, forms of art, writing and meaning of symbols. The meaning of the philosophy of visual symbols in audio-visual texts such as TV commercials, animated films and television programs as objects, can be perceived by its meaning through the relation between the signs. According to Peirce (in Kris Budiman article) that in the typology of the sign arranged in tripartite found that the characteristics of the arbitrator and conventional is only found in one sub-type of sign called as a symbol. Sign with arbitrary characteristic according to Peirce is referred to as a conventional sign called a symbol. And sign without arbitrary characteristic called as an icon. According to Saussure's terminology, the opposite characteristic, based on resemblance, is an iconic sign. And the symptoms can be called iconicity .

The phenomenon in the text image in the production of symbols or logos is the ability of the creator to raise issues that are thematically developing in the society today. Suppose the emergence of brands / symbols that lift the local cultural products, but has been worldwide popular such as batik and keris. Keris is a visual object. It is a local icon of the nation's ancestral creative product and has become a global icon. It is proven by the confession of batik and keris as world heritage by UNESCO. Batik was created to have certain functions according to the existing motif on it, made with perseverance and high patience. Such as a keris, is made with patience, power and peace of mind by the keris-maker. Having a variety of pamor and has a high philosophy meaning is a cultural heritage of ancestors who have lived in the social life of Indonesia, especially Java. Iconicity in the symbol or logo is arising the theme of the keris. According to Kris Budiman, the problem of this sign iconicity phenomenon, while diving by drinking water, we will also be able to enter one other classical theme in semiotics, the case of metaphor relatively smooth. Then some leading bank companies bring the keris-maker and the keris icon in the visualization of the ads product. Long time ago it has raised keris as an icon in positioning its newspaper in the middle of society like Suara Merdeka newspaper in Central Java. Looking at all these things, it seems that local idioms are able to be expected to lift products by advertising that makes the company's brand image strong. It also raises the idioms of cultural products into elements in the visualization of advertising that has become a necessity in the globalization of the world of competition about the increasingly local image of global establishment. So if we pay attention, the existence of the keris symbol as a form of appreciation of the symbolism values of the pamor keris as a cultural artifact of our nation that is noble. When we examined more deeply to the work of a keris-maker especially keris, keris is simplification of language which express so complicated language of life at that time concerning behavior, religion, politics, ideals, technology, etc. It can be said that keris is like a poetry, one word has millions of meaning as well as one part (rincikan) on the keris has a very deep meaning. At the time of making the keris, the keris-maker performs inner behavior with certain prayers in starting his work. The prayer he recites will be a power that indirectly serves as the "content" of the keris. From the different prayers will produce a different tangguh keris, then this prayer will create a unique keris pamor.

The symbolism meaning of the keris visuals, Keris 
as a giver of security for the user in the form of a sharp weapon is more functioning as a weapon with supernatural power (esoteric essence), whose main function no longer lies in the sharpness of the keris as a tool weapon in the violence. It exists from its internal strength, that is a kind of imagination and spirit formed from the 'yoni' power (inner power) or prayer that is obscene (such as mantram, asmaan, rajah). So the meaning of this philosophy is represented by visually applying the iconic identity of keris in symbols, logos, and brands to be represented in metaphorical rhetoric with the vision and the mission semiotically. So the creator in this case the designer is to create the abstraction of tradition symbol of keris which having full of meaning. The work of the symbolic form of abstraction in conception is a form of modern art by utilizing the idiom of tradition as the basic element of its formation. So it is as a new interpretation of a keris visual idiom embodied in a work of logo is utilizing visual artistic conception of traditional iconicity. So that the use of idioms are contextually reduced because of the processing of the artists in interpreting the form symbolically. Thus the presence of the idiom of tradition is no longer as a thematic in showing idea but as a textual symbol offered by artists to give a freedom of interpretation.

\section{Conclusion}

The existence of local cultures or cultures used in thematic logos / brands is undeniable used as a creative strategy to differentiate the competitors. However, the cultural value carried forward is actually ambiguous or forced by the vision and image mission of the actual consumer products themselves, but it is legitimated in the logo / symbol. As currency because of the culture of the keris as a value to be sold to commercial value consumers, is a contradiction with the noble value of keris. It could be the cultural theme as an attempt to fortify and preserve the keris to be introduced back to the society that in fact has lost its identity in the midst of mass culture (hegemony) entry with postmodernism images today.

The iconicity value of the symbolic keris visualization wrapped with the visual image of the logo as a whole does not necessarily only as an accessories, where the visual is placed symmetrically or placed in the middle. This is the visualization of keris just like sticking, so it is forced impressively. If it integrates with the values in the provincial symbol / logo as a whole, then the content of the meaning is inseparable. Because the symbol of the keris is widely used almost in all provinces and districts as a sense of passion to build Indonesia that carry the value of unity throughout the archipelago.

Keris in visual rhetoric interpreted as a symbol, logo, and brand is a metaphor of its creators in this case the designer to realize the vision of the company's mission or institution to become the identity (corporate identity). From the point of semiotics visual or semiology, the keris changes its meaning and form visually in symbol, logo, and brand symbolically its daily reality not as a complementary of custom fashion.

\section{REFERENCES}

[1] Dharsono, The Revitalization of Values of Cultural Precepts in Traditional Javanese Arts, Arts and Design Studies Journal. www.iiste.org ISSN 2224-6061 (Paper) ISSN 2225059X (Online) Vol.51, 2017.

[2] Guntur. Kerisology, Arts of Science and Technology (Kerisologi, Seni Ilmu Pengetahuan dan Teknologi). Surakarta: Penerbit: ISI Press, 2007.

[3] Guritno, Haryono Haryo. (Javanese Keris between Mystics and Reason Keris Jawa antara Mistik dan Nalar), Jakarta: penerbit: PT. Indonesia Kebanggaanku, 2006.

[4] Haryoguritno, Haryono. Keris, Magic Pow-er-Benefits-TuahMystery (Keris, Daya Mag- ic-Manfaat-Tuah-Misteri). Semarang: Dhahara Interprize, 2007.

[5] Haryono, Timbul. Performing Arts and Fine Arts in Art Archeology Perspective (Seni Pertunjukan dan Seni Rupa dalam Perspektif Arkeologi Seni). Surakarta: ISI Press, 2008]

[6] Mayer, Kathy. Unpacking Ad Temptation Sensation (Membongkar Sensasi Godaan Iklan). Yogyakarta: Jalasutra, 2012]

[7] ]Kartika, Dharsono Sony. Artistic Creation, the Encounter of Modern Traditions in the Artistic Performing Paradigm (Kreasi Artistik,Perjumpaan Tradisi Modern dalam Paradigma Kekaryaan Seni). Karanganyar: Citra Sain, 2016]

[8] Kris Budiman. Iconic Semiotics Literature and Visual Art (Ikonisitas Semiotika Sastra dan Seni Visual). Penerbit:Buku Baik, Yogyakarta, 2005]]]

[9] Kris Budiman. Visual Semiotics (Semiotika Visual). Yogyakarta: Penerbit: Buku Baik, 2004

[10] Pamungkas, Ragil. Knowing Javanese Keris, Java's "Magical" Weapon (Mengenal Keris Jawa, Senjata "Magis" Masyarakat Jawa). Yogyakarta: Penerbit Narasi, 2007

[11] Piliang. Y.A. Hypersemiotics, Cultural Studies Interpretation of the Death of Meaning (Hipersemiotika, Tafsir Cultural Studies atas Matinya Makna). Bandung: Jalasutra, 2003

[12] Wibawa, Prasida. Tosan Aji, Enchantment of Cultural Achievement (Tosan Aji, Pesona Jejak Prestasi Budaya. Jakarta: PT. Gramedia Pustaka, 2008

[13] http://arkeologi.web.id/, accessed $2^{\text {th }}$ February 2015)

[14] http://senibudaya.timlo.net, accessed $19^{\text {th }}$ September 2012 